\title{
Purification and Properties of Spore-lytic Enzymes from Clostridium perfringens Type A Spores
}

\author{
By DAVID E. GOMBAS $\dagger$ AND RONALD G. LABBE* \\ Food Microbiology Laboratory, Department of Food Science \& Nutrition, \\ University of Massachusetts, Amherst, Massachusetts 01003, USA
}

(Received 23 October 1984; revised 17 January 1985)

\begin{abstract}
Spores of Clostridium perfringens contain at least two spore-lytic enzymes active in hydrolysing cortical peptidoglycan. One enzyme has been purified 1800 -fold and has a molecular weight of 17400 determined from chromatography on Sephadex G-75. Two protein bands were apparent after SDS-PAGE. The isolated enzyme was investigated for response to temperature, $\mathrm{pH}$, ionic strength and enzyme inhibitors, and for mode of action. A second enzyme activity, differing from the first in apparent molecular weight (29800) as determined by gel exclusion chromatography, and also in its $\mathrm{pH}$ optimum and activity on cortical substrate, was also isolated, although not purified to the same extent.
\end{abstract}

\section{INTRODUCTION}

Peptidoglycan has structural significance in all bacteria. In vegetative bacteria and bacterial spores peptidoglycan forms the major part of the rigid cell wall and spore cortex respectively. In spores, the cortex must by hydrolysed during germination in order for the spore protoplast to emerge. In Clostridium perfringens, deficiencies in or damage to the cortex-lytic enzymes can result in superdormant spores, or spores which, although viable, cannot germinate and grow out without an exogenous source of lytic agent such as lysozyme (Duncan et al., 1972).

Several researchers have described the cortex-lytic initiation protein (IP) detected in culture filtrates of vegetative and sporulating C. perfringens (Cassier \& Ryter, 1971; Duncan et al., 1972; Franceschini \& Labbe, 1979; Labbe et al., 1981). Ando (1979) and ourselves (Gombas \& Labbe, 1981) have reported a spore-lytic enzyme (SLE) which can be extracted from cleaned $C$. perfringens spores. Lytic enzymes associated with sporulation and spores of $C$. perfringens are important for at least two reasons. First, it is the activity of an autolytic system which causes the release (in the intestine) of the mature spore and the concomitant release of an enterotoxin which is responsible for gastroenteritis. Secondly, SLE is involved in the germination of spores of this organism. It is the germination and subsequent vegetative cell multiplication which results in the large numbers of cells associated with food-borne illness due to this organism.

The biochemical properties of partially purified IP have been reported (Labbe et al., 1981). Here we report the isolation and characteristics of SLE from cleaned C. perfringens spores, and present evidence for a second spore-lytic enzyme activity.

\section{METHODS}

Organism. The organism used was Clostridium perfringens type A, strain NCTC 8798 (Hobbs serotype 9).

Media and sporulation. Spores were prepared and cleaned as described by Franceschini \& Labbe (1979). Spores to be used to prepare SLE extracts were harvested from approximately 300 litres of sporulation medium, resulting

† Present address: Campbell Institute for Research \& Technology, Camden, NJ 08101, USA.

Abbreviations: IP, initiation protein; SLE, spore-lytic enzyme; UME, urea/mercaptoethanol; CMC, carboxymethyl cellulose; DTT, dithiothreitol; NEM, $\mathrm{N}$-ethylmaleimide; CMPS, chloromercuriphenylsulphonic acid; FDNB, fluorodinitrobenzene. 
in a final washed spore suspension of approximately $3 \times 10^{13}$ spores. Final spore suspensions contained $>95 \%$ phase-bright spores, as determined by phase-contrast microscopy. Cleaned spores were harvested by centrifuging at $5^{\circ} \mathrm{C}$ and stored as frozen pellets until use.

Enzyme extraction and purification. Spores were heat activated $\left(75^{\circ} \mathrm{C}, 15 \mathrm{~min}\right)$, then germinated with $0 \cdot 1 \mathrm{M}-$ sodium nitrite, as previously described (Gombas \& Labbe, 1981). Germinated spores were extracted for $2 \mathrm{~h}$ with $7.2 \mathrm{M}$-urea plus $10 \%(\mathrm{v} / \mathrm{v})$ mercaptoethanol, $\mathrm{pH} 2.85(\mathrm{UME})$ at $45^{\circ} \mathrm{C}$. The spores were separated from the extract by centrifugation $(3020 \mathrm{~g}, 10 \mathrm{~min})$ at $20^{\circ} \mathrm{C}$, and re-extracted for an additional $2 \mathrm{~h}$ in fresh UME (secondary UME extract). The two extracts were treated similarly, but separately, through the purification. The extracts were dialysed overnight against approximately 100 vols distilled water at $4{ }^{\circ} \mathrm{C}$. Insoluble material was removed from the crude retentate by centrifugation at $3020 \mathrm{~g}$ for $10 \mathrm{~min}$ at $5{ }^{\circ} \mathrm{C}$, resulting in a 1.8 -fold increase in purity (Table 1 ). Phosphate-treated SLE was prepared by adding sufficient $0.5 \mathrm{M}$-sodium phosphate, $\mathrm{pH} 6.0$, to the supernatant to bring the phosphate concentration to $60 \mathrm{~mm}$. After $5-10 \mathrm{~min}$ at $22^{\circ} \mathrm{C}$, the precipitate was removed by centrifugation, without measurable loss of SLE activity. Phosphate-treated SLE was used in some studies of crude SLE properties. SLE in solution was concentrated by placing the enzyme preparation in distilled water-washed dialysis tubing, and dehydrating by osmosis on a bed of polyethylene glycol 20000 (Sigma). Activity recovery ranged from 65 to $100 \%$. Optimum recovery required post-concentration dialysis (usually in 60 or $500 \mathrm{~mm}$ phosphate buffer, pH 6.0). Any precipitate that formed during the concentration process was collected and redissolved overnight in a small volume of $0.5 \mathrm{M}$-phosphate buffer. If it contained significant SLE activity, it was added back to the concentrate. The phosphate-treated material was dialysed overnight against run buffer $(60 \mathrm{mM}-$ sodium phosphate, $\mathrm{pH} 6 \cdot 0$, plus $0 \cdot 2 \%$ sodium azide) and then added to a carboxymethyl cellulose (CMC) column.

CMC (0.72 mequiv. $\mathrm{g}^{-1}$; Sigma) was hydrated and charged as described by Himmelhoch (1971). The CMC column $(1.5 \mathrm{~cm}$ i.d. $\times 8.3 \mathrm{~cm}$ bed height) was washed with at least 10 bed volumes of $0.5 \mathrm{M}$-sodium phosphate, pH 6.0, then equilibrated with 3-4 bed volumes of run buffer. Phosphate-treated SLE was pumped onto the column at $0.6 \mathrm{ml} \mathrm{min} \mathrm{m}^{-1}\left(20^{\circ} \mathrm{C}\right)$. The column was washed with run buffer until the protein elution was negligible (34 bed volumes). SLE was collected by isocratic elution: SLE from the primary UME extract was eluted with $125 \mathrm{~mm}-\mathrm{NaCl}$ in run buffer (Table 1, IIA); SLE from the secondary UME extract was eluted with $65 \mathrm{mM}-\mathrm{NaCl}$ in run buffer (Table 1, IIB); eluted fractions were collected in acid cleaned tubes ( $3 \mathrm{ml}$ per tube). Fractions containing the highest specific activity were pooled $\left(>10000 \mathrm{U} \mathrm{mg}^{-1}\right.$ for the primary extract, $>50000 \mathrm{U} \mathrm{mg}^{-1}$ for the secondary extract). Pooled eluates were then concentrated to less than $10 \mathrm{ml}$ and dialysed against run buffer before fractionation on Sephadex G-75 Superfine.

SLE was mixed with $70 \%(w / v)$ sucrose and layered onto the gel column $(2.6 \mathrm{~cm}$ i.d. $\times 97 \mathrm{~cm}$ bed height $)$. SLE was eluted at $0.5 \mathrm{ml} \mathrm{min} \mathrm{m}^{-1}$ and $4 \mathrm{ml}$ fractions were collected. Two peaks with spore-lytic activity were recovered and designated $\beta$-SLE and $\alpha$-SLE, for the earlier and later eluting activities, respectively (Fig. $1 a$ ). Fractions with the highest specific activity were pooled for each extract : $>85000 \mathrm{U} \mathrm{mg}^{-1}$ for $\alpha$-SLE of the primary UME extract; $>100000 \mathrm{U} \mathrm{mg}^{-1}$ for $\alpha$-SLE of the secondary UME extract; and $>26000 \mathrm{U} \mathrm{mg}^{-1}$ for $\beta$-SLE of the primary UME extract. These preparations were used for characterization of the properties of SLE.

Molecular weight determination by gel exclusion chromatography. The same Sephadex G-75 Superfine column and procedures were used as described above. Molecular weight standards were mixed with $70 \%$ sucrose and layered onto the gel under the buffer. Sample volumes were $<2 \%$ of the gel bed volume. The void volume was determined by using dextran blue 2000 (Sigma). Molecular weight standards used were: ovalbumin (43000, Sigma), chymotrypsinogen (25000, Sigma), horse myoglobin (17200, Sigma) and ribonuclease (13700, Pharmacia). The elution volume of standards was determined from the absorbance at $280 \mathrm{~nm}$; the elution volume of SLE was determined at peak activity, as assayed on coatless spores (see below).

$S D S-P A G E$. This was done by the method of Laemmli \& Favre (1973), as modified by Pandey \& Aronson (1979). Acrylamide gels $(18 \%, w / v)$ were run in a slab gel apparatus (Hoefer Scientific Instruments, SE-600) on the day of preparation. The gels were stained using Coomassie Blue R-250 and recorded either by photography or by densitometer measurements using a soft laser scanning densitometer (Biomed Instruments, Fullerton, Calif., USA). The following proteins $(8-10 \mu \mathrm{g}$ of each; all from Sigma) were used as molecular weight standards: phosphorylase $b(94000)$, bovine serum albumin (67000), ovalbumin (43000), alcohol dehydrogenase (37700), myoglobin (17200) and lysozyme (14400).

pH optimum determination. Buffers ( $30 \mathrm{~mm}$-cation concentration) were prepared at $\mathrm{pH}$ values in the range $2.75-$ 11.0 as follows: sodium acetate, $\mathrm{pH} 4 \cdot 1-5.6$; citrate/phosphate, $\mathrm{pH} 2.75-6.7$ and sodium phosphate, $\mathrm{pH} 6 \cdot 1-11.0$. Buffer (1.90-1.95 ml) was mixed with either coatless spores or cortical fragments to give a final volume of $2.00 \mathrm{ml}$ and a final $\mathrm{OD}_{400}$ of $0 \cdot 4-0 \cdot 5$. The enzyme, dissolved in $60 \mathrm{~mm}$-sodium phosphate, $\mathrm{pH} 6 \cdot 0$, was mixed into the prewarmed $\left(37^{\circ} \mathrm{C}\right)$ substrate/buffer mixture and assayed for activity. The $\mathrm{pH}$ of the post-reaction mixture differed from the original $\mathrm{pH}$ by $<0 \cdot 1$ unit.

Effects of cations. The salt solutions used had a final $\mathrm{pH}$ of $8 \cdot 0 \pm 0 \cdot 1$ at $25^{\circ} \mathrm{C}$. They were mixed with assay spores to give a final volume of $2.00 \mathrm{ml}$ and an $\mathrm{OD}_{400}$ of $0.4-0.5$. Cobalt chloride samples were assayed at $600 \mathrm{~nm}$ due to interfering absorbance at $400 \mathrm{~nm}$. Enzyme $(25 \mu \mathrm{l})$, in $60 \mathrm{~mm}$-sodium phosphate, pH 6.0, was mixed into the 
prewarmed $\left(37^{\circ} \mathrm{C}\right)$ substrate/salt solution, and assayed for activity. The $\mathrm{pH}$ of the post-reaction mixture differed from the original by $<0 \cdot 1$ unit.

Enzyme solubility. Samples of the enzyme were pipetted into equal volumes of buffer $\left(200 \mathrm{U} \mathrm{ml}^{-1}\right.$, final concentration) and held at $25^{\circ} \mathrm{C}$ for up to $15 \mathrm{~min}$. Samples were centrifuged $(3020 \mathrm{~g}, 10 \mathrm{~min})$ to remove precipitated material, and supernatants were collected and assayed. In some cases, pelleted material was redissolved by adding a small volume of $0.5 \mathrm{M}$-buffer to the centrifuge tube, vortexing, and storing overnight at $4{ }^{\circ} \mathrm{C}$. Material which did not redissolve was removed by centrifugation.

Temperature stability. The enzyme was incubated in $60 \mathrm{~mm}$-sodium phosphate, $\mathrm{pH} 6.0$, in a water bath adjusted to various temperatures, $\pm 1^{\circ} \mathrm{C}$. Temperature was measured with a thermometer placed in an identical tube with a similar volume of water. At various times, $25 \mu l$ samples were removed and assayed at $37^{\circ} \mathrm{C}$ in $2.00 \mathrm{ml} 20 \mathrm{~mm}$ sodium phosphate buffer, $\mathrm{pH} 7.8$, containing assay spores. Activity is reported as the percentage activity remaining as compared with the preincubation activity.

Protease activity. Wells ( $3 \mathrm{~mm}$ diam.) were made in $3-5 \mathrm{~mm}$ deep plates of $0.2 \%(\mathrm{w} / \mathrm{v})$ casein in $2 \%(\mathrm{w} / \mathrm{v})$ agar (buffered to $\mathrm{pH} 7.8$ with $10 \mathrm{~mm}$-sodium phosphate) and were filled with $20-25 \mu \mathrm{l}$ enzyme. Trypsin $\left(1 \mathrm{mg} \mathrm{ml}^{-1}\right.$; Sigma) was used as a positive control. Plates were stored at $25^{\circ} \mathrm{C}$ for up to $5 \mathrm{~d}$. Protease activity appeared as a clear zone surrounding the well. Protease activity was also assayed on Azocoll (Calbiochem) by the method of Cheng \& Aronson (1977).

Enzyme inhibitors. Dithiothreitol (DTT; Sigma), $N$-ethylmaleimide (NEM; Sigma), mercuric chloride (Fisher Scientific, Fairlawn, NJ, USA), and potassium ferricyanide (Sigma) were dissolved in $60 \mathrm{~mm}-\mathrm{Tris} / \mathrm{HCl}, \mathrm{pH} 8.0$. p-Chloromercuriphenylsulphonic acid (CMPS; Sigma) was dissolved in $25 \mathrm{mM}$-Tris/maleate, pH 6.0. Coatless spores $(50 \mu \mathrm{l})$ were mixed with each reagent or with buffer alone to give a final volume of $2.00 \mathrm{ml}$ and $\mathrm{OD}_{400}$ of 0.4 0.5 , and prewarmed to $37^{\circ} \mathrm{C}$. The enzyme $\left(25 \mu \mathrm{l}\right.$ in $60 \mathrm{mM}$-sodium phosphate) was added and the $\mathrm{OD}_{400}$ measured. CMPS-treated samples were assayed at $600 \mathrm{~nm}$. The percentage inhibition was calculated from the ratio of activity of SLE in the reagent to activity in buffer alone. In some experiments, enzyme was incubated with $1.0 \mathrm{ml}$ DTT or buffer at $37^{\circ} \mathrm{C}$ for $2 \mathrm{~min}$, and then $1.0 \mathrm{ml}$ reagent was added and the mixture incubated for $2 \mathrm{~min}$ before addition of assay spores.

Lysozyme assay. Micrococcus lysodeikticus cells (Sigma) were suspended in $2.0 \mathrm{ml}$ of either sodium phosphate buffer, $\mathrm{pH} 7.8$, or citrate/phosphate buffer, $\mathrm{pH} 4.5$, and pre-warmed to $37^{\circ} \mathrm{C}$. Enzyme was added to the suspension, and the $\mathrm{OD}_{400}$ measured for $25 \mathrm{~min}$. Lysozyme $\left(0.1 \mathrm{mg} \mathrm{ml}^{-1}\right.$; Sigma) was used as a positive control.

$N$-Acetylglucosaminidase assay. $p$-Nitrophenyl- $N$-acetylglucosaminide (Sigma) was dissolved in sodium phosphate, $\mathrm{pH} 7 \cdot 8$, or citrate/phosphate, $\mathrm{pH} 4 \cdot 5$, and pre-warmed to $37^{\circ} \mathrm{C}$. Enzyme was added to the solution, and the $A_{405}$ measured for $25 \mathrm{~min}$. $\mathrm{N}$-Acetylglucosaminidase (Sigma) was used as a positive control.

Reducing sugars. Generation of reducing sugars during enzyme hydrolysis of cortical fragments was measured by the ferricyanide method (Thompson \& Shockman, 1968) using $N$-acetylglucosamine (Sigma) as the standard.

$N$-terminal amino groups. Measurement of $N$-terminal amino groups generated during enzyme hydrolysis of cortical fragments was by the fluorodinitrobenzene (FDNB) procedure described by Ghuysen et al. (1966).

SLE activity assay. SLE was assayed as previously described (Gombas \& Labbe, 1981) using as substrate coatstripped C. perfringens spores (Franceschini \& Labbe, 1979), or cortical fragments from $C$. perfringens spores prepared as described by Hashimoto et al. (1972). Complete removal of spore coats was verified by electron microscopy. Unless otherwise stated, a wavelength of $400 \mathrm{~nm}$ was used for all activity assays, which were done in a Beckman 25 spectrometer equipped with a kinetic system. One unit (U) of activity was defined as a decrease in the $\mathrm{OD}_{400}$ of $0.01 \mathrm{~min}^{-1}$.

Protein assay. Protein was measured by the dye-binding method of Bradford (1976), using bovine serum albumin (Sigma) as the standard.

\section{RESULTS}

\section{Purification of SLE}

The purification protocol used (Table 1) resulted in a 15-16\% recovery of SLE activity from the primary UME extract, with an overall purification of approximately 600 -fold and 200 -fold for $\alpha$ - and $\beta$-SLE respectively. When analysed by SDS-PAGE, $\alpha$-SLE was found to contain one major band (Fig. $2 c ; 64 \%$ of the total stained protein based on densitometer tracings, Fig. $2 d$ ) of molecular weight 29500 , a lesser band ( $11 \%$ of total protein, molecular weight 22500 ), and four lower molecular weight bands. The $\beta$-SLE fraction was found to contain bands at all six molecular weights (Fig. $2 a$ ), in approximately the same ratio as in $\alpha$-SLE, and five additional protein bands with apparent molecular weights of 38000,33000,32000, 22400, and 17500 (with relative peak intensities of $30.5,30.5,22,33$, and $15 \%$, respectively, as compared with the 

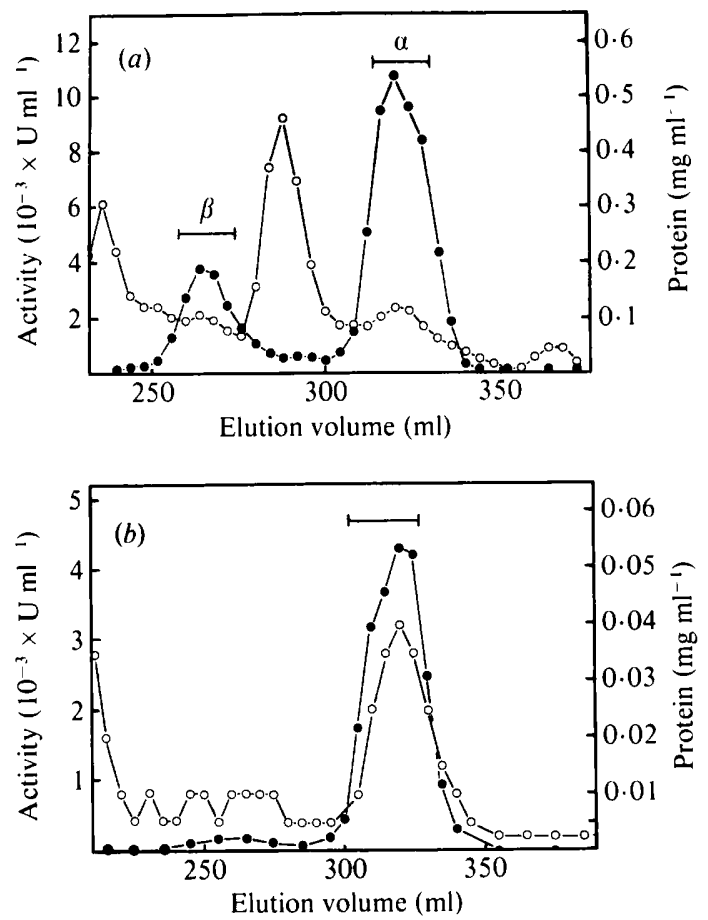

Fig. 1. Separation of CMC-purified SLE on Sephadex G-75 SF. (a) Material eluted from CMC column with $125 \mathrm{mM}-\mathrm{NaCl}$. (b) Material eluted from CMC column with $65 \mathrm{~mm}-\mathrm{NaCl}$. Fractions indicated by bars were pooled for further study. Activity $(O)$ and protein $(O)$ were assayed as described in Methods. Void volume $=150 \mathrm{ml}$. The values are from a single experiment.

molecular weight 29500 major band). No protein bands were detected having molecular weights of greater than 38000 . This $\beta$-SLE preparation was used for the characterization of the properties of $\beta$-SLE.

Purification of the secondary UME extract by the modified protocol (i.e. $65 \mathrm{mM}-\mathrm{NaCl}$ instead of $125 \mathrm{mM}-\mathrm{NaCl}$ for the isocratic elution of activity from $\mathrm{CMC}$ ) resulted in approximately $30 \%$ less activity eluted from $\mathrm{CMC}$, but an increase in the overall purification to approximately 1800 fold (Table 1). Only a barely detectable $\beta$-SLE fraction, less than $2 \%$ of the $\alpha$-SLE activity, was eluted from Sephadex G-75 by this modified protocol (Fig. $1 b$ ). When analysed by SDS-PAGE, the $\alpha$-SLE fraction was found to contain only the 29500 and the 22500 bands (Fig. $2 f$ ), in a ratio of $8: 1$, based on densitometer tracings (Fig. $2 g$ ). This $\alpha$-SLE fraction was used for the characterization of the properties of $\alpha$-SLE.

When phosphate-treated SLE was assayed on coatless spores, a sharp pH optimum was found at approximately 4.25 , with a lesser peak (approximately $70 \%$ of the $\mathrm{pH} 4.25$ peak) over the range of $\mathrm{pH} 6 \cdot 6-8.4$ (Fig. $3 a$ ). Negligible activity was found at $\mathrm{pH}$ values $\leqslant 3 \cdot 1$ or $\geqslant 8.75$. Essentially the same profile was found at $\mathrm{pH}$ values $\leqslant 5.0$ if activity was assayed on cortical fragments, although the secondary peak at $\mathrm{pH} 6 \cdot 2-8 \cdot 0$ was less prominent.

When $\alpha$-SLE was assayed on coatless spores over the same $\mathrm{pH}$ range, the $\mathrm{pH}$ optimum was $7 \cdot 2-8.4$ (Fig. $3 b$ ). When $\alpha$-SLE was assayed on cortical fragments at $\mathrm{pH} 7 \cdot 7$ or $4 \cdot 2$, negligible activity was found.

When $\beta$-SLE was assayed on coatless spores over the same $\mathrm{pH}$ range, the activity profile was essentially the same as that of the phosphate-treated SLE (Fig. $3 c$ ): the pH optimum was at approximately $\mathrm{pH} 4$, with a lesser peak at $\mathrm{pH} 6.75$ having $70 \%$ of the optimum activity. When $\beta$ SLE was assayed on cortical fragments, it had the same activity $\left(\mathrm{U} \mathrm{ml}^{-1}\right)$ on cortical fragments as on coatless spores at $\mathrm{pH} 3.6$, but only $18 \%$ of the activity expressed on coatless spores when assayed at $\mathrm{pH} 7.7$. Subsequently, $\alpha$-SLE activity was assayed at $\mathrm{pH} 7 \cdot 8-8.1$ and $\beta$-SLE activity was assayed at $\mathrm{pH} 4 \cdot 2$. 

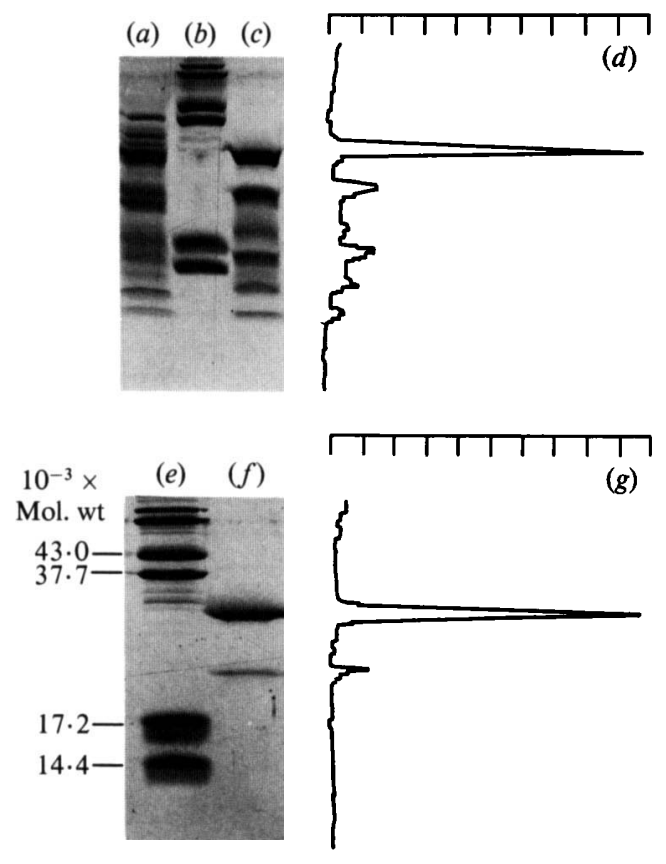

Fig. 2. SDS-PAGE of purified SLE eluted from Sephadex G-75 SF column. (a-d) Material from CMC column eluted with $125 \mathrm{mM}-\mathrm{NaCl}$ before separation on Sephadex column: (a) $\beta$-SLE, $(b)$ molecular weight standards, $(c) \alpha$-SLE, $(d)$ densitometer tracing of $(c)$. $(e-g)$ Material from CMC column eluted with $65 \mathrm{mM}-\mathrm{NaCl}$ before separation on Sephadex column: $(e)$ molecular weight standards, $(f) \alpha$-SLE, $(g)$ densitometer tracing of $(f)$.

Table 1. Summary of SLE purification protocol

The values are from a single experiment.

Purification step

I Crude dialysate

Centrifuged

Phosphate-treated

Concentrated

IIA Pooled CMC fractions

(eluted with $125 \mathrm{~mm}-\mathrm{NaCl}$ )

Concentrated

Pooled Sephadex G-75 fractions $\alpha$-SLE

$\beta$-SLE

IIB Pooled CMC fractions

(eluted with $65 \mathrm{~mm}-\mathrm{NaCl}$ )

Concentrated

Pooled Sephadex G-75 fractions $\alpha$-SLE

\begin{tabular}{|c|c|c|c|}
\hline $\begin{array}{l}\text { Protein } \\
\left(\mathrm{mg} \mathrm{ml}^{-1}\right)\end{array}$ & $\begin{array}{l}\text { Specific } \\
\text { activity } \\
\left(\mathrm{U} \mathrm{mg}^{-1}\right)\end{array}$ & $\begin{array}{c}\text { Recovery } \\
(\%)\end{array}$ & $\begin{array}{l}\text { Purification } \\
\text { (fold) }\end{array}$ \\
\hline $\begin{array}{l}0.76 \\
0.56 \\
0 \cdot 15 \\
0.755\end{array}$ & $\begin{array}{r}213 \\
380 \\
4100 \\
4700\end{array}$ & $\begin{array}{r}100 \\
107 \\
107 \\
85\end{array}$ & $\begin{array}{c}1.0 \\
1.8 \\
19 \\
22\end{array}$ \\
\hline 0.275 & 31700 & 65 & 150 \\
\hline ND & ND & 47 & ND \\
\hline $\begin{array}{l}0.55 \\
0.57\end{array}$ & $\begin{array}{r}141000 \\
41900\end{array}$ & $\begin{array}{c}10 \\
5 \cdot 6\end{array}$ & $\begin{array}{l}660 \\
200\end{array}$ \\
\hline $0 \cdot 07$ & 75000 & ND & 350 \\
\hline ND & ND & ND & ND \\
\hline 0.25 & 390000 & ND & 1800 \\
\hline
\end{tabular}

ND, Not determined.

Properties of SLE

Temperature stability. $\alpha$-SLE in 60 mM-sodium phosphate, $\mathrm{pH} 6 \cdot 0$, retained $90 \%$ of its activity after incubation at $42.5^{\circ} \mathrm{C}$ for $45 \mathrm{~min}$ (Fig. 4). However, incubation of the isolated enzyme at higher temperatures resulted in rapid inactivation, with $88 \%$ loss of activity after $2.5 \mathrm{~min}$ at $57.5^{\circ} \mathrm{C}$. Both purified $\alpha$-SLE and phosphate-treated crude SLE were stable at $4{ }^{\circ} \mathrm{C}$ for several weeks. Purified $\alpha$ - and $\beta$-SLE each retained $>70 \%$ activity after several weeks of frozen storage. 


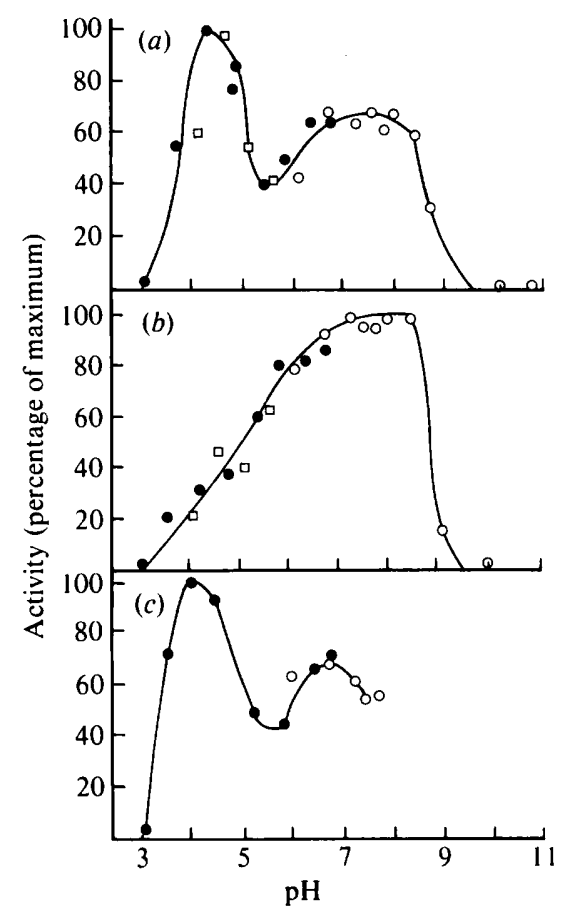

Fig. 3

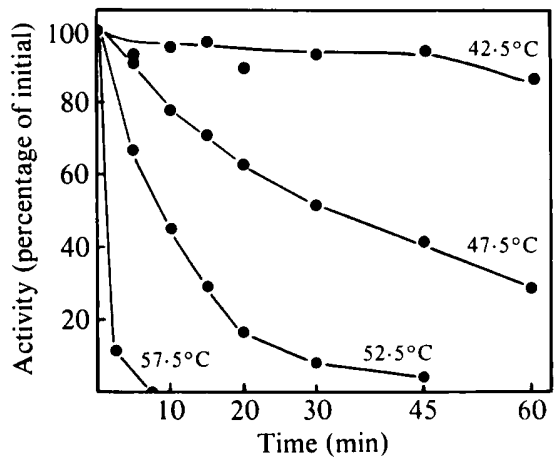

Fig. 4

Fig. 3. Effect of pH on activity of SLE. (a) Phosphate-treated SLE; (b) $\alpha$-SLE; (c) $\beta$-SLE. All activities were assayed using coatless spores in $30 \mathrm{~mm}$-buffer; the $100 \%$ activities were $150 \mathrm{U} \mathrm{ml}^{-1}$. Citric acid/sodium phosphate; $\square$, acetic acid/sodium acetate; $O$, sodium phosphate. The values are representative of those obtained in duplicate experiments.

Fig. 4. Temperature stability of $\alpha$-SLE. Enzyme was held at the indicated temperature in $60 \mathrm{~mm}-$ sodium phosphate, $\mathrm{pH} 7.8$. Residual activity was assayed on coatless spores in 20 mm-sodium phosphate, $\mathrm{pH} 7.8$, at $37^{\circ} \mathrm{C}$. The values are representative of those obtained in duplicate experiments.

Ionic strength effects. Optimum activity of $\alpha$-SLE occurred at a monovalent cation concentration of approximately $25 \mathrm{mM}$, plus $5 \mathrm{mM}$-Tris/maleate, $\mathrm{pH} 7 \cdot 8$, with a rapid decrease in activity at lower monovalent cation concentrations and a gradual decrease at higher concentrations. The activity profile was identical for the cations sodium, potassium and ammonium. Activity in $5 \mathrm{~mm}$-buffer alone was $11-12 \%$ of optimum, while activity in $100 \mathrm{mM}$ salt was approximately $35 \%$ of optimum.

Maximum activity in the presence of the divalent cations calcium or magnesium occurred at the lower concentration of $2.5-10 \mathrm{mM}$. Activity dropped off rapidly at higher concentrations, with $40 \%$ of maximum at $25 \mathrm{~mm}$-cation, and $<10 \%$ of maximum at $>50$ mM-cation. No detectable activity was found in the presence of the divalent cation cobalt in the range of 1$100 \mathrm{mM}$, and only $35 \%$ of maximum at $0.1 \mathrm{mM}$.

At $\mathrm{pH} 7 \cdot 9, \alpha$-SLE responded to the sodium phosphate buffer concentration as it did to other monovalent cations, with maximum activity at a buffer concentration of $20-25 \mathrm{mM}$, falling off rapidly at higher or lower concentrations (Fig. 5). Negligible activity was found at buffer concentrations $>100 \mathrm{mM}$. At buffer concentrations of $<10 \mathrm{mM}$ solubility of $\alpha$-SLE was $<20 \%$ of the maximum. Solubility gradually increased at higher buffer concentrations until reaching $>80 \%$ at buffer concentrations of $>50 \mathrm{~mm}$. Enzyme solubility in $20-25$ mM-sodium phosphate was approximately $50 \%$. Activity which was lost due to precipitation could be quantitatively recovered after resolubilization of pelleted material in $0.5 \mathrm{M}$-buffer.

Molecular weight. Analysis by gel exclusion chromatography on Sephadex G-75 indicated a Stokes radius equivalent to a molecular weight of 17400 for $\alpha$-SLE, and 29800 for $\beta$-SLE (Fig. 


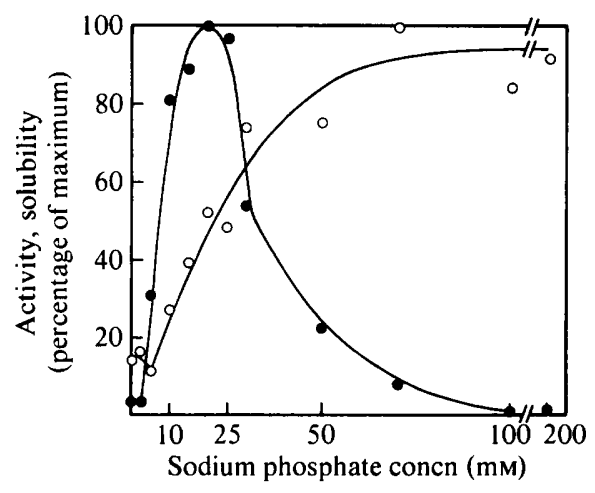

Fig. 5. Effect of sodium phosphate, pH 7.8, on activity ( $\bigcirc)$ and solubility (O) of $\alpha$-SLE. Activity was assayed in $20 \mathrm{~mm}$-phosphate as described in Methods. The values are representative of those obtained in duplicate experiments.

$1 a$ ). Analysis by SDS-PAGE indicated a molecular weight for the major protein band in both $\alpha$ and $\beta$-SLE of 29500 (Fig. 2). The reasons for the apparent discrepancy in the molecular weight measured by the two procedures are discussed below.

Enzyme inhibitors. SLE activity on coatless spores was inhibited by thiol-active agents to various degrees: mercuric chloride $(0.05 \mathrm{mM})$ inhibited $\alpha$-SLE at $\mathrm{pH} 7.8$ by $>97 \%$ and CMPS $(10 \mathrm{mM})$ inhibited phosphate-treated SLE at pH 6.0 by $80 \%$. NEM concentrations as high as $50 \mathrm{~mm}$ were only $40-60 \%$ inhibitory to $\alpha$-SLE, while DTT was slightly stimulatory at $0 \cdot 1-10 \mathrm{mM}$. Potassium ferricyanide ( $50 \mathrm{~mm}$ ) was $>90 \%$ inhibitory to $\alpha$-SLE. All inhibitory effects of thiolactive agents were partially prevented by pre-incubation of enzyme with equimolar DTT, except for mercuric chloride, which required a $1000: 1$ ratio for $50 \%$ retention of activity. Potassium ferricyanide inhibition was not prevented by equimolar DTT.

Proteolytic activity. Neither phosphate-treated SLE, $\alpha$-SLE, nor $\beta$-SLE showed detectable proteolytic activity on casein plates after $5 \mathrm{~d}$. Proteolysis assays on Azocoll at $\mathrm{pH} 4.5$ and 7.8 were also negative.

\section{Mode of action}

$\alpha$-and $\beta$-SLE were both negative for muramidase and $N$-acetylglucosaminidase activity when each was incubated with $M$. lysodeikticus or $p$-nitrophenyl- $N$-acetylglucosaminide, respectively. Incubation with cortical fragments indicated $\beta$-SLE to have approximately equal activity on germination of coatless spores and hydrolysis of cortical fragments. At equivalent levels of spore-lytic activity, the $\alpha$-SLE preparation had $<2 \%$ of the corticolytic activity of the $\beta$-SLE preparation. However, $\alpha$-SLE was able to slowly hydrolyse cortical fragments to about the same final percentage change in $\mathrm{OD}_{400}$ as $\beta$-SLE (32\% and $37 \%$ for $\alpha$-and $\beta$-SLE respectively). When cortical fragments, incubated with $\alpha$-SLE or $\beta$-SLE until the maximum decrease in $\mathrm{OD}_{400}$ had occurred, were assayed for reducing power, the $\alpha$-SLE sample was not significantly different from untreated cortex, while $\beta$-SLE samples were strongly positive. Samples analysed for FDNB-reactive groups were not significantly different from untreated cortical fragments, indicating the absence of additional free amino groups following treatment with $\alpha$ - or $\beta$-SLE.

\section{DISCUSSION}

Although studies have shown that spores of Bacillus cereus contain at least four different cortex-degrading enzymes (Warth, 1972), no previous reports have indicated more than one spore-lytic activity from spores of $C$. perfringens. As that activity is undoubtedly involved in germination of spores, it was considered of interest to compare some of the properties of the isolated enzyme with the observed characteristics of the spore. In order to minimize misinterpretation of enzyme properties because of competing or co-activities in the enzyme 
preparation, steps were taken to purify the enzyme from any potentially interfering proteins. It was only during the final steps of the purification that the SLE activity resolved into two fractions, which were designated $\alpha$-SLE and $\beta$-SLE. Because of the higher concentration of $\alpha-$ SLE activity in the preparation, efforts were focused on elucidating its properties. Preliminary trials indicated that the protocol used for purification of the primary UME extract would yield a preparation with a single protein component, as determined by SDS-PAGE. However, in scaling up from the $10^{10}$ spores per extraction of the preliminary trials to the $10^{13}$ spores used for this study, several previously undetected proteins became evident in the final $\alpha$-SLE fraction of the primary extract. Decreasing the ionic strength of the eluent for the CMC elution of the secondary UME extract decreased SLE recovery but yielded a purer $\alpha$-SLE preparation. However, it is not known if the improved purification was due to the lower ionic strength eluent, or because the contaminating proteins were not present in the secondary extract.

After purification of $\alpha$-SLE to two protein bands as determined by SDS-PAGE, its properties were investigated. Like the phosphate-treated preparation and many other spore enzymes, $\alpha-$ SLE is not inherently heat resistant, being inactivated by temperatures far below those used in thermal activation, such as used on the spores from which the SLE was extracted. Consequently, both SLE activities must be stabilized or otherwise protected in vivo. By contrast, Srivastava \& Fitz-James (1981) reported that partially purified cortex-lytic enzyme and purine nucleoside hydrolase from Bacillus subtilis spores were stable for $20 \mathrm{~min}$ at $75^{\circ} \mathrm{C}$ and $50^{\circ} \mathrm{C}$, respectively.

An $N$-acetylmuramyl-L-alanine amidase, extracted from sporulating cells of $C$. perfringens (Traci, 1977), was reported to be stimulated by cobalt ions. In contrast, $\alpha$-SLE was totally inactive in millimolar concentrations of cobalt, and was inhibited by concentrations which were reported to be stimulatory to the amidase.

Germination of bacterial spores, including those of $C$. perfringens, has been found to be greatly stimulated by various cations, including potassium and calcium (Ando, 1978; Levinson \& Feeherry, 1975). By contrast, activity of $\alpha$-SLE, as well as the more crude preparation, was very sensitive to ionic strength in vitro, showing activity only in a narrow range of monovalent cation concentrations, and an even narrower range of divalent cations.

Like the cruder preparation, $\alpha$-SLE demonstrated an unexpected solubility profile in various ionic strength buffers. The property of insolubility in the narrow ionic range in which SLE has activity, and the loss of enzyme activity as solubility increases, may be related; e.g. low ionic strength may cause the enzyme to precipitate and adsorb to its substrate, while high ionic strength may preclude contact between the two. The isoelectric points of both SLE activities are $>\mathrm{pH} 8$ (data not shown), so at a physiological $\mathrm{pH}$, SLE is positively charged. As its substrate, cortical peptidoglycan, is negatively charged (Gould \& Dring, 1974), the attraction between the two could be electrostatic, and ions in solution might interfere with the interaction.

An optimal UME extraction of a spore pellet yielded about 52000 SLE units per $10^{12}$ spores. A specific activity of $3.9 \times 10^{5} \mathrm{U} \mathrm{mg}^{-1}$ has been attained for $\alpha$-SLE, which has an apparent molecular weight of approximately 17000 . Assuming near $100 \%$ efficiency in the extraction of $\alpha$ SLE, and an even distribution of active enzyme from the spores extracted, these values indicate a maximum of 4700 molecules per spore, or about $0.05 \%$ of the total spore dry weight. Higher actual values for molecular weight (see below) or specific activity, or separate consideration of $\beta$ SLE, would decrease the estimated number of molecules per spore.

The resolution of $\alpha$ - and $\beta$-SLE on Sephadex G-75 was initially thought to be an artefact, since only one activity peak was resolved by other purification methods, notably Sephadex G-100. However, no such discrepancy was observed with other proteins on Sephadex G-75 and G-100 columns. Further, $\beta$-SLE has a very different $\mathrm{pH}$ optimum from $\alpha$-SLE, and a different degree of activity on cortical fragments (although both are apparently capable of lysing cortical fragments). On the other hand, SDS-PAGE of both fractions indicated that not only the major protein band but also the minor protein band of $\alpha$-SLE appeared to be the same as in the $\beta$-SLE fraction. This might be easily understandable if $\alpha$-SLE were a subunit of $\beta$-SLE; however, the major protein fraction of $\alpha$-SLE on SDS-PAGE was 1.7 times larger than indicated by the elution volume on Sephadex G-75. $\beta$-SLE, on the other hand, had the same apparent molecular weight on Sephadex G-75 as the major protein fraction on SDS-PAGE. Moreover, considering 
the good resolution of $\alpha$-SLE and $\beta$-SLE on Sephadex G-75, none of the molecular weight 30000 $\beta$-SLE protein should have been included in the $\alpha$-SLE fractions. This apparent paradox would be expected if $\alpha$-SLE had more than a typical affinity for Sephadex G-75, and was retarded on the column, thus only appearing to have a smaller molecular weight, while $\beta$-SLE, for reasons unknown, did not have this affinity for Sephadex, and so eluted normally. Such an affinity for Sephadex gels has been reported for amidases (Herbold \& Glaser, 1975; Williamson \& Ward, 1979) and glucosaminidases (Taylor et al., 1980; Williamson \& Ward, 1981). Whether this is the case or not, elution on Sephadex G-75 Superfine has been the only technique we have found to resolve the two activities.

Another lytic enzyme which appears in the culture filtrate during growth of $C$. perfringens has been called initiation protein (IP), so termed for its ability to initiate germination in sensitized spores (Cassier \& Sebald, 1969; Duncan et al., 1972). This enzyme also attacks both coatless spores and isolated cortical fragments (Labbe et al., 1981). Partially purified IP has been found to have an apparent molecular weight of 100000 (Labbe et al., 1981), which is three to six times larger than the enzymes described here. It is apparent, therefore, that $C$. perfringens does produce more than one spore-lytic enzyme. Synthesis of more than one lytic enzyme is not unusual for spore-forming bacteria. For example, Kingan \& Ensign (1968) reported three autolytic enzymes from sporulating cells of Bacillus sphaericus. Brown et al. $(1977,1978)$ reported two separate lytic enzymes present in $B$. cereus spores : a 'surface' or coat-associated enzyme and a core-associated enzyme; while both enzymes lysed cortical fragments, only the core-associated enzyme could germinate coat-stripped spores.

The relationship between $\alpha$-SLE and $\beta$-SLE is unknown. Exhaustive efforts were made using non-denaturing PAGE and isoelectric focusing to determine which of the protein bands were actually associated with SLE activity. Thus far, we have been unsuccessful in eluting or otherwise detecting any SLE activity from electrophoretic gels; this precludes the use of immunochemistry to test the identity of the two activities when neither is in a homogeneous preparation. Although $\alpha$-SLE and $\beta$-SLE enzyme activities are corticolytic, the specific nature of each was not determined. Cortical fragments reacted with $\beta$-SLE had a substantially higher concentration of reducing sugars than non-reacted fragments, but showed no increase in free amino groups. Cortical fragments reacted with $\alpha$-SLE had neither more reducing sugars nor more terminal amino groups than the untreated substrate, although it is possible that the latter was due to a high background of amino groups in the cortex (Ghuysen et al., 1966). The results, however, suggest that $\alpha$-SLE and $\beta$-SLE lack amidase and peptidase activities.

This work was supported by the US Army Research Office and by USDA Hatch Project no. 484.

\section{REFERENCES}

ANDo, Y. (1978). Biochemical mechanisms of ionic germination of spores of Clostridium perfringens type A. In Spores VII, pp. 75-79. Edited by G. Chambliss \& J. C. Vary. Washington, DC: American Society for Microbiology.

ANDo, Y. (1979). Spore lytic enzyme released from Clostridium perfringens spores during germination. Journal of Bacteriology 140, 59-64.

BRADFORD, M. M. (1976). A rapid and sensitive method for the quantitation of microgram quantities of protein utilizing the principle of protein-dye binding. Analytical Biochemistry 72, 248-254.

Brown, W. C., Cuhel, R. L. \& Greer, C. (1977). Isolation and properties of a surface-bound cortexlytic enzyme from spores of Bacillus cereus $T$. In Spore Research (1976), pp. 335-349. Edited by A. Barker, J. Wolf, D. Ellar, G. Dring \& G. Gould. London: Academic Press.

Brown, W. C., Vellom, D., Schnepf, E. \& Greer, C. (1978). Purification of a surface-bound hexose- aminidase from spores of Bacillus cereus T. FEMS Microbiology Letters 3, 247-251.

CASSIER, M. \& RYTER, A. (1971). Sur un mutant de Clostridium perfringens donnant des spores sans tuniques à germination lysozyme-dépendant. $A n$ nales de l'Institut Pasteur 121, 717-732.

Cassier, M. \& Sebald, M. (1969). Germination lysozyme-dépendante des spores de Clostridium perfringens ATCC 3624 après traitement thermique. Annales de l'Institut Pasteur 117, 312-324.

Cheng, Y.-S. B. \& Aronson, A. I. (1977). Characterization and function of intracellular proteases in sporulating Bacillus cereus. Archives of Microbiology 115, 61-66.

Duncan, C. L., LabBe, R. G. \& Reich, R. R. (1972). Germination of heat- and alkali-altered spores of Clostridium perfringens type $\mathrm{A}$ by lysozyme and an initiation protein. Journal of Bacteriology 109, 550559.

Franceschini, T. J. \& LABbE, R. G. (1979). Sensitivity 
of chemically treated spores of Clostridium perfringens type A to an initiation protein. Microbios 25, $85-91$.

Ghuysen, J.-M., Tipper, D. J. \& Strominger, J. L. (1966). Enzymes that degrade bacterial cell walls. Methods in Enzymology, 8, 685-699.

Gombas, D. E. \& LaBBE, R. G. (1981). Extraction of spore-lytic enzyme from Clostridium perfringens spores. Journal of General Microbiology 126, 37-44.

Gould, G. W. \& DRING, G. J. (1974). Mechanisms of spore heat resistance. Advances in Microbial Physio$\log y$ 11, 137-164.

Guinand, M., Vacheron, M. J., Michel, G. \& TIPPER, D. J. (1979). Location of peptidoglycan lytic enzymes in Bacillus sphaericus. Journal of Bacteriology 138, 126-132.

Hashimoto, T., Frieben, W. \& Conti, S. (1972). Kinetics of germination of heat-injured Bacillus cereus spores. In Spores V, pp. 409-415. Edited by H. Halvorson, R. Hanson \& L. Campbell. Washington, DC: American Society for Microbiology.

Herbold, D. R. \& GlaSer, L. (1975). Bacillus subtilis $\mathrm{N}$-acetylmuramic acid L-alanine amidase. Journal of Biological Chemistry 250, 1676-1682.

Himmelhoch, S. R. (1971). Chromatography of proteins on ion-exchange absorbents. Methods in Enzymology, 22, 273-286.

Kingan, S. L. \& Ensign, J. (1968). Isolation and characterization of three autolytic enzymes associated with sporulation of Bacillus thuringiensis var. thuringiensis. Journal of Bacteriology 96, 629-638.

Labbe, R. G., TANG, S. \& Franceschini, T. J. (1981). Partial purification and characterization of an initiation protein for germination from Clostridium perfringens spores. Biochimica et biophysica acta 678, 329-333.

LaEmmli, U. K. \& FaVRe, M. (1973). Maturation of the head of bacteriophage T4. Journal of Molecular Biology 80, 575-599.
LEVInSON, H. S. \& FeEherRy, F. E. (1975). Influence of cations on nitrate-induced germination of Bacillus megaterium QMB1 551 spores. In Spores VI, pp. 495505. Edited by P. Gerhardt, R. Costilow \& H. Sadoff. Washington, DC: American Society for Microbiology.

Pandey, N. K. \& ARonson, A. 1. (1979). Properties of the Bacillus subtilis spore coat. Journal of Bacteriology 137, 1208-1218.

SRivastava, O. P. \& Fitz-James, P. (1981). Alteration by heat activation of enzymes localized in spore coats of Bacillus subtilis. Canadian Journal of Microbiology 27, 408-416.

TAYlor, C., Rogers, H. J. \& WARD, J. B. (1980). The autolytic endo- $\beta$ - $N$-acetylglucosaminidase of Bacillus subtilis: purification and properties. Society for General Microbiology Quarterly 7, 73-74.

Thompson, J. S. \& Shockman, O. D. (1968). A modification of the Park and Johnson reducing sugar determination suitable for the assay of insoluble materials : its application to bacterial cell walls. Analytical Biochemistry 22, 260-268.

TRACI, P. A. (1977). Isolation and characterization of an autolysin present in spores, sporulating cells and vegetative cells of Clostridium perfringens type A. $\mathrm{PhD}$ dissertation, University of Wisconsin, Madison, USA.

W ARTH, A. D. (1972). Action of spore lytic enzymes on the cortex. In Spores $V$, pp. 28-34. Edited by $\mathrm{H}$. Halvorson, R. Hanson \& L. Campbell. Washington, DC: American Society for Microbiology.

Williamson, R. \& WaRd, J. B. (1979). Characterization of the autolytic enzymes of Clostridium perfringens. Journal of General Microbiology 114, 349--354.

Williamson, R. \& WaRD, J. B. (1981). Deficiency of autolytic activity in Bacillus subtilis and Streptococcus pneumoniae is associated with a decreased permeability of the wall. Journal of General Microbiology 125, 325-334. 